$\mathbf{R}_{\text {ESEARCH }} \mathbf{P}_{\text {APER }} \longrightarrow$ FOOD SCIENCE e ISSN-2230-9403 — Visit us : www.researchjournal.co.in Volume 8 | Issue 1 | April, 2017 | 21-24 DOI : 10.15740/HAS/FSRJ/8.1/21-24

\title{
Studies on nutritional profile of different parts of Moringa oleifera (Leaf, flower and pod)
}

\author{
R.B. Kshirsagar, A.R. Sawate, B.M. Patil and M.A. Zaker
}

The leaves, fruit, flowers and immature pods of Moringa oleifera are used as a highly nutritive vegetable. The mandate of current study was to explore the nutritional worth of Moringa oleifera because of its easily availability and mostly use. The raw materials were analyzed for the proximate like moisture, fat, protein, fibre, ash and carbohydrate and mineral profile. The composition profiling of Moringa oleifera indicated that leaves, flowers and pods are good source of protein, fat, crude fibre and ash content. Moringa oleifera leaves powder had highest protein content $(24.14 \%)$ followed by flower (16.1\%) and pods (13.8\%). Moringa oleifera leaves contain high calcium, magnesium, phosphorous and iron content than flowers and pods. Moringa oleifera pod powder was found to be higher in potassium content $(2847 \mathrm{mg}$ ) followed by leaves and flowers. Moringa oleifera leaves noted $6951 \mathrm{IU}$ of vitamin A, $329 \mathrm{mg}$ of vitamin C and $480 \mathrm{mg}$ of vitamin E. Moringa oleifera leaves are having significant amount of vitamin A, C and E. However flowers and pods of Moringa oleifera are also reported considerable amount of vitamin C.Among the parts of Moringa oleifera total flavonoids and tannin content in the pods was found to be highest than flowers and leaves. Moringa oleifera leaves powder had highest alkaloid content (5.68 \%) followed by flower (3.87 \%) and pods (3.28\%) .

Key Words : Moringa oleifera, Proximate composition, Phytochemicals, Vitamins

How to cite this article : Kshirsagar, R.B., Sawate, A.R., Patil, B.M. and Zaker, M.A. (2017). Studies on nutritional profile of different parts of Moringa oleifera (Leaf, flower and pod). Food Sci. Res. J., 8(1): 21-24, DOI : 10.15740/HAS/FSRJ/8.1/21-24. 